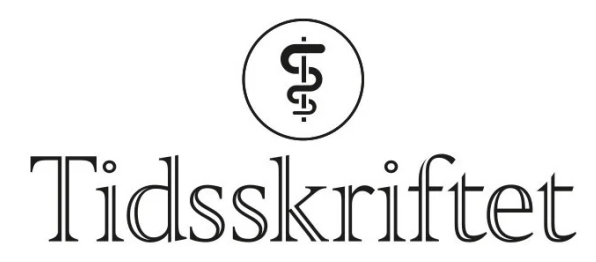

DEN NORSKE LEGEFORENING

\title{
Re: Kiropraktorutdanning i Norge nå!
}

\author{
BREV TIL REDAKTØREN
}

\section{JØRGEN JEVNE}

Jørgen Jevne (f. 1984) er fysioterapeut/kiropraktor. Ingen oppgitte interessekonflikter

Email: jorgen.jevne@gmail.com

Jeg vil først og fremst si takk til Stein Arne Evensen for en betimelig, velskrevet og ydmyk kommentarartikkel (11). Det er sjelden å se liknende åpenhet og løsningsorientering i helsevesenet.

Videre må jeg stille meg 10o \% bak kommentarinnlegget til kiropraktor Ole Christian Kvammen. Det er påfallende at en hel profesjon i flere kretser blir beskrevet som uvitenskapelig, grunnløs og til og med schizofren, når man ser hvor stort forskningsengasjementet er blant kiropraktorer. De trenger bare muligheten.

I Danmark har forskning innenfor kiropraktorenes virkeområder stått sterkt i mange år. Forskningen foregår i stor grad på bakgrunn av fondsmidler og statlig støtte. På tross av et relativt lite forskningsmiljø produserer kiropraktorene i Danmark viten som publiseres i anerkjente tidsskrifter. Et godt eksempel på dette er oktoberutgaven i 2013 av tidsskriftet Best Practice \& Research Clinical Rheumatology (2). Dette var en spesialutgave som omhandlet «Low back pain». Av totalt 12 artikler i denne utgaven, var fire skrevet av forfattere med bakgrunn fra de forskjellige forskningsavsnittene i Danmark. Videre har flere norske kiropraktorer doktorgrad, eller er under doktorgradsutdanning, og har publikasjoner i JAMA, Spine og BMC Musculoskeletal Disorders (3)-(5).

Å hevde at kiropraktikken som helhet er kvakksalveri, alternativt og useriøst, synes jeg er en håpløs generalisering uten rot i virkeligheten. Det er ganske enkelt feil.

Følgelig mener jeg Kvammens beskrivelse er korrekt. Det står sannsynligvis mer på økonomisk og politisk, og kanskje også medisinsk, vilje, enn det står på kunnskapen, engasjementet og ønsket om å forske blant kiropraktorer.

\section{LITTERATUR}

1. Evensen SA. Kiropraktorutdanning i Norge nå! Tidsskr Nor Legeforen 2014; 134: 597-8. [PubMed]

2. van der Windt DA, Dunn KM. The high prevalence of low-back pain has been highlighted for many years, but until recently,awareness of its impact in the population was limited. Preface. Best Pract Res Clin Rheumatol 2013; 27: 571-3. [PubMed] [CrossRef] 
3. Wilkens P, Scheel IB, Grundnes O et al. Effect of glucosamine on pain-related disability in patients with chronic low back pain and degenerative lumbar osteoarthritis: a randomized controlled trial. JAMA 2010; 304: 45-52. [PubMed] [CrossRef]

4. Wilkens P, Scheel IB, Grundnes O et al. Prognostic factors of prolonged disability in patients with chronic low back pain and lumbar degeneration in primary care: a cohort study. Spine 2013; 38: 65-74. [PubMed] [CrossRef]

5. Aartun E, Degerfalk A, Kentsdotter L et al. Screening of the spine in adolescents: inter- and intrarater reliability and measurement error of commonly used clinical tests. BMC Musculoskelet Disord 2014; 15:37. [PubMed] [CrossRef]

Publisert: 29. april 2014. Tidsskr Nor Legeforen. DOI:10.4045/tidsskr.14.0462

(C) Tidsskrift for Den norske legeforening 2023. Lastet ned fra tidsskriftet.no 26. april 2023. 